\title{
Soilborne Phytophthora and Pythium Diversity From Rhododendron in Propagation, Container, and Field Production Systems of the Pacific Northwest
}

\author{
Jerry E. Weiland, ${ }^{1, \dagger}$ Carolyn. F. Scagel, ${ }^{1}$ Niklaus J. Grünwald, ${ }^{1}$ E. Anne Davis, ${ }^{1}$ Bryan R. Beck, ${ }^{1}$ Zachary S. L. Foster, ${ }^{2}$ \\ and Valerie J. Fieland ${ }^{2}$ \\ ${ }^{1}$ Horticultural Crops Research Laboratory, U.S. Department of Agriculture Agricultural Research Service, Corvallis, OR 97330 \\ ${ }^{2}$ Oregon State University, Department of Botany and Plant Pathology, Corvallis, OR 97331
}

\begin{abstract}
Rhododendron root rot is a severe disease that causes significant mortality in rhododendrons. Information is needed about the incidence and identity of soilborne Phytophthora and Pythium species causing root rot in Pacific Northwest nurseries in order to better understand the disease etiology and to optimize disease control strategies. The last survey focusing solely on soilborne oomycete pathogens in rhododendron production was conducted in 1974. Since then, advances in pathogen identification have occurred, new species may have been introduced, pathogen communities may have shifted, and little is known about Pythium species affecting this crop. Therefore, a survey of rootinfecting Phytophthora and Pythium species was conducted at seven nurseries from 2013 to 2017 to (i) document the incidence of root rot damage at each nursery and stage of production, (ii) identify soilborne oomycetes infecting rhododendron, and (iii) determine whether there are differences in pathogen diversity among nurseries and production systems. Rhododendrons from propagation, container, and field systems were sampled and Phytophthora and Pythium species were isolated from the roots and collar region. Root rot was rarely evident

suggesting that Phytophthora species are the primary cause of severe root rot and that most contamination by these pathogens comes in after the propagation stage. In total, 20 Pythium species and 11 Phytophthora species were identified. Pythium cryptoirregulare, Pythium aff. macrosporum, Phytophthora plurivora, and Phytophthora cinnamomi were the most frequently isolated species and the results showed that Phytophthora plurivora has become much more common than in the past. Phytophthora diversity was also greater in field systems than in propagation or container systems. Risks for Phytophthora contamination were commonly observed during the survey and included placement of potting media in direct contact with field soil, the presence of dead plants that could serve as continuous sources of inoculum, and the presence of excess water as a result of poor drainage, overirrigation, or malfunctioning irrigation equipment. In the past, research on disease development and root rot disease control in rhododendron focused almost exclusively on Phytophthora cinnamomi. More research is needed on both of these topics for the other root-infecting species identified in this survey.
\end{abstract} in propagation systems, which were dominated by Pythium species. However, severe root rot was much more common in container and field systems where the genus Phytophthora was also more prevalent,
Keywords: ornamentals, oomycetes, pathogen detection, pathogen diversity, woody ornamentals, yield loss and economic impacts
Rhododendrons (Rhododendron species and cultivars) are an important component of the Pacific Northwest (PNW) nursery industry, with an annual value of \$11.6 million (USDA National Agricultural Statistics Service 2015). They are grown for their spring flowers and evergreen leaves. Nursery production of this crop is often severely compromised by root rot, with losses of up to $100 \%$ reported (White 1937). Several Phytophthora species cause root rot, including Phytophthora cactorum (Lebert \& Cohn) J. Schröt., Phytophthora cinnamomi Rands, Phytophthora citricola Sawada or Phytophthora

${ }^{\dagger}$ Corresponding author: J. E. Weiland; Jerry.Weiland@usda.gov

Funding: This work was funded, in part, by the USDA-ARS (projects CRIS 2072-22000-043-00D, CRIS 2072-21000-048-00D, and CRIS 2072-21000053-00D), the Floral and Nursery Research Initiative (project 0500-00059001-00D), the Northwest Center for Nursery Crop Research, and the Horticultural Research Institute. Mention of trade names or commercial products in this publication is solely for the purpose of providing specific information and does not imply recommendation or endorsement by the U.S. Department of Agriculture. USDA is an equal opportunity provider and employer.

*The $\boldsymbol{e}$-Xtra logo stands for "electronic extra" and indicates that two supplementary tables are published online.

The author(s) declare no conflict of interest.

Accepted for publication 19 January 2020.

This article is in the public domain and not copyrightable. It may be freely reprinted with customary crediting of the source. The American Phytopathological Society, 2020 plurivora T. Jung \& T.I. Burgess, and Phytophthora cryptogea Pethybr. \& Laff., as well as other less common species (Hoitink and Schmitthenner 1974b; Parke et al. 2014; Weiland et al. 2018). Pythium species, such as Pythium cryptoirregulare (Garzón, Yánez, and G.W. Moorman) and Pythium prolatum F. F. Hendrix \& W. A. Campb., may also cause root rot (Botha and Crous 1992; Hendrix and Campbell 1966; Weiland et al. 2018).

To better understand rhododendron root rot in the PNW, information is needed about the current diversity of soilborne Phytophthora and Pythium species affecting rhododendron production in this region. The last systematic survey of soilborne Phytophthora species that infect rhododendron was published in 1974 (Hoitink and Schmitthenner 1974b). Many advances in pathogen identification using DNA sequence analysis have been made since then and species abundances may have changed in the intervening $\geq 40$ years. New species may also be present. Much of the more recent information about Phytophthora species diversity on rhododendron is based on nursery surveys of aboveground plant organs (stems, leaves) that were conducted in response to the quarantine pathogen, Phytophthora ramorum (Blomquist et al. 2016; Dart and Chastagner 2007; Knaus et al. 2015; Prospero et al. 2013), and may therefore not be reflective of soilborne species diversity. In addition, results from these surveys are often combined across aboveground and belowground plant samples, host species, or sample sources (e.g., plants, irrigation water, containers, and potting media or soil), making it difficult to make inferences about the diversity of soilborne oomycete pathogens that specifically affect rhododendron production (Benson et al. 1982; Bienapfl and Balci 2014; Parke et al. 2014; Schwingle et al. 2007). Pythium species have rarely been included in these surveys despite their potential to also cause root rot (Botha and Crous 1992; Hendrix and Campbell 1966; Weiland et al. 2018). 
The last comprehensive survey of foliar and soilborne Phytophthora species in PNW nurseries showed that Phytophthora cinnamomi and Phytophthora plurivora were common on four plant hosts, including rhododendron (Parke et al. 2014). Parke et al. (2014) also showed that there was relatively little Phytophthora inoculum in the propagation stage of the production cycle, but it was unclear how species diversity might change once newly propagated plants are moved into subsequent container or field production systems. To obtain a more indepth assessment of the diversity of soilborne oomycete pathogens that infect rhododendron and to get a better understanding of whether oomycete diversity changes among different systems (propagation, container, and field) in rhododendron production, a survey of soilborne Phytophthora and Pythium species of rhododendron in PNW nurseries was conducted. The objectives were to (i) document the incidence of root rot damage caused by soilborne pathogens at each nursery and stage of production, (ii) identify soilborne oomycetes infecting rhododendron in PNW nurseries, and (iii) determine whether there are differences in pathogen diversity among rhododendron nurseries and production system types.

\section{Materials and Methods}

Sample collection and processing. Rhododendrons were sampled from propagation, container, and field production systems at seven nurseries from 2013 to 2017 (nurseries A to G). Fifty to 100 samples (one sample per plant) were obtained from three nurseries for each type of system (Table 1). Plants (rooted cuttings) from propagation systems were 3 to 6 months old and were located inside greenhouses at nurseries C, D, and E. Plants from container systems were 1 to 3 years old and were located in an outdoor canyard (nursery B) or in both outdoor canyards and greenhouses (nurseries A and C). Plants from field systems were 1 to 5 years old and were always located in uncovered (no canopy), outdoor fields at nurseries B, F, and G. In each case, plants from multiple sites (benches, beds, or blocks) and cultivars were primarily sampled at each nursery during the cool, wet fall, winter, or spring months when temperatures were between 5 and $15^{\circ} \mathrm{C}$ to control for any potential seasonal effect. However, previous research from Oregon found little to no effect of either season or sample year on Phytophthora diversity from nursery crops, including rhododendron (Parke et al. 2014). Identification labels were missing or unavailable at some nurseries; therefore, it was not always possible to obtain cultivar data for many of the rhododendrons sampled. However, a frequency list of all symptomatic, identified cultivars from which isolates were obtained was compiled (Supplementary Table S1). The incidence of root rot damage was estimated from each site by counting the number of plants exhibiting symptoms of root rot (chlorosis, stunting, wilting, and plant death) per total number of plants for each cultivar affected.

Rhododendrons with symptoms of root rot were sampled at random from both container and field sites. Symptoms of root rot were largely absent on plants at propagation facilities; therefore, a similar number of asymptomatic plants were sampled at random for this type of production system. In each production system, the entire plant was collected and all leaves and stems located $6 \mathrm{~cm}$ above the soil line were cut off and discarded. Soil or potting media was shaken off from the root system, roots were washed in running tap water, and necrotic plant tissues were excised from the roots or from lesions extending up into the root collar region. Similar tissues were sampled from plants without symptoms from the propagation facilities. All tissues were surface disinfested for $1 \mathrm{~min}$ in $0.5 \% \mathrm{NaOCl}$ and for $30 \mathrm{~s}$ in $70 \%$ $\mathrm{EtOH}$, and they were then air dried for up to $1 \mathrm{~min}$ in a laminar flow hood before plating on PARP (pimaricin, ampicillin, rifampicin, pentachloronitrobenzene), a semiselective medium for the isolation of Pythiaceous species (Kannwischer and Mitchell 1978).

A minimum of 50 isolates were obtained from each nursery $\times$ production system combination and 624 isolates were obtained in total. All isolates were identified on the basis of the internal transcribed spacer (ITS) sequence, compared with published type or authenticated sequences when available (Supplementary Table S2), and confirmed by morphology as described previously (Weiland et al. 2018). Isolates identified as Phytophthora pini were additionally confirmed by sequencing the translation elongation factor $1 \alpha$ and cytochrome $\mathrm{c}$ oxidase subunit I genes (Hong et al. 2011). Isolates identified as Phytophthora plurivora were confirmed using a PCR-restriction fragment length polymorphism assay (Knaus et al. 2015). Pythium oopapillum/dissotocum hybrids were identified by ITS sequences alone.

Data analyses. Frequency data (disease incidence and isolation frequency) were analyzed using a $\chi^{2}$ test of independence with Yates' correction (Mantel 1974) using Statistica (version 13; TIBCO Software Inc.). Species richness curves, computed with EstimateS version 9.1.0 (Colwell 2013), were used to evaluate whether sampling detected the majority of species at each nursery. The Phytophthora and Pythium species occurring in each nursery were counted and diversity was quantified by calculating species richness, abundance, Shannon's diversity index, and the inverse Simpson index (Morris et al. 2014). Differences in mean alpha diversity among systems were determined using analysis of variance (ANOVA) of the Shannon and inverse Simpson indexes followed by a post hoc Tukey's honestly significant difference test. The Levene test for homogeneity of variance and the Shapiro-Wilk test for normality were used to test for deviations in the data from the assumptions of ANOVA. Nonmetric multidimensional scaling of Bray-Curtis dissimilarities was used to visualize the differences in community composition between samples using the function metaMDS from the vegan R package (Oksanen et al. 2019).

\section{Results}

The incidence of root rot varied among nurseries and systems (Table 1). Propagation systems had the least amount of root rot $(0$

Table 1. Incidence of root rot across three production systems at seven rhododendron nurseries

\begin{tabular}{lccc}
\hline Production stage & Nursery & $\begin{array}{c}\text { Symptomatic plants }(\boldsymbol{n}) / \text { total number of } \\
\text { plants }(\boldsymbol{\%})^{\mathbf{y}}\end{array}$ & Range $^{\mathbf{z}}$ \\
\hline Propagation & C & $0 / 600(0) \mathrm{a}$ & $0-0$ \\
& D & $5 / 550(1) \mathrm{a}$ & $0-10$ \\
Container & E & $0 / 980(0) \mathrm{a}$ & $0-0$ \\
& A & $22 / 191(12) \mathrm{c}$ & $4-25$ \\
Field & B & $107 / 781(14) \mathrm{c}$ & $4-50$ \\
& C & $36 / 239(15) \mathrm{c}$ & $6-36$ \\
Propagation & B & $63 / 205(31) \mathrm{d}$ & $7-90$ \\
Container & F & $331 / 808(41) \mathrm{e}$ & $5-90$ \\
Field & G & $46 / 1,820(3) \mathrm{b}$ & $1-25$ \\
\hline
\end{tabular}

${ }^{y}$ Number of rhododendrons with symptoms of root rot/total number of plants (\%). Values within a column followed by different lowercase letters or uppercase letters are significantly different at $P<0.050$.

${ }^{\mathrm{z}}$ Range of disease incidence observed across sites at each nursery or for each system type. 
to $10 \%$ incidence), with only five symptomatic plants occurring at nursery D. Container systems, on the other hand, had low to moderate amounts of root rot (4 to $50 \%$ ), depending on the site sampled. Field systems at nurseries B and $\mathrm{F}$ had several sites with a high incidence of root rot (up to $90 \%$ ), resulting in a greater number of symptomatic plants overall compared with container systems. However, the field system at nursery $G$ had the lowest incidence of root rot compared with any other container or field system surveyed.

A total of 31 oomycete taxa (11 Phytophthora and 20 Pythium species) were identified from the 624 isolates obtained during the survey (Table 2). The genus Pythium was isolated twice as often (67\%) as the genus Phytophthora (33\%), with Pythium cryptoirregulare (32\%), Pythium aff. macrosporum (13\%), Pythium dissotocum (6\%), Pythium irregulare (4\%), Pythium attrantheridium (3\%), and Pythium sylvaticum (3\%) being the most frequently detected Pythium species. Phytophthora plurivora (14\%), Phytophthora cinnamomi (10\%), Phytophthora pseudocryptogea (3\%), and Phytophthora cambivora (2\%) were the most commonly isolated Phytophthora species. These 10 oomycete species accounted for $90 \%$ of all isolates found. Species richness curves approached an asymptote, indicating that few additional species would be detected if the sampling effort were increased (Fig. 1).

There were broad shifts in the richness and abundance of both pathogen genera among production systems. Overall oomycete species richness (across all Phytophthora and Pythium species) was approximately double in field systems compared with either propagation or container systems (Fig. 1). This was primarily attributable to the large increase in the number of Phytophthora species isolated from field systems while the number of Pythium species remained relatively constant across the three system types (Table 2). Pythium dominated propagation systems, accounting for $>92 \%$ of all species and isolates obtained (Figs. 2 and 3). Phytophthora cinnamomi was the only Phytophthora species isolated from this system type (nursery D only). Although the number of Pythium species remained fairly constant across system types (Table 2), the genus Pythium was isolated less frequently from container $(60 \%$ of all isolates) and field systems (47\%) than from propagation systems (98\%) (Figs. 2 and 3). Phytophthora species, on the other hand, were isolated more frequently from container (40\% of all isolates) and field

Table 2. Phytophthora and Pythium species isolated from rhododendron plants in propagation, container, and field nursery production systems at seven rhododendron nurseries

\begin{tabular}{|c|c|c|c|c|c|}
\hline \multirow[b]{2}{*}{ Genus and species } & \multirow[b]{2}{*}{ Isolation frequency (\% total) } & \multirow[b]{2}{*}{ Total isolates $(n)$} & \multicolumn{3}{|c|}{ Isolates $(n)$} \\
\hline & & & Propagation & Container & Field \\
\hline \multicolumn{6}{|l|}{ Phytophthora ${ }^{\mathrm{y}}$} \\
\hline Phytophthora cambivora & 2.4 & $15 \mathrm{~b}$ & $0 \mathrm{~A}$ & $0 \mathrm{~A}$ & $15 \mathrm{bB}$ \\
\hline Phytophthora chlamydospora & 0.6 & $4 \mathrm{a}$ & $0 \mathrm{~A}$ & $0 \mathrm{~A}$ & $4 \mathrm{aB}$ \\
\hline Phytophthora cinnamomi & 9.5 & $59 \mathrm{c}$ & $4 \mathrm{~A}$ & $21 \mathrm{bB}$ & $34 \mathrm{dC}$ \\
\hline Phytophthora crassamura & 0.2 & $1 \mathrm{a}$ & 0 & 0 & $1 \mathrm{a}$ \\
\hline Phytophthora pseudocryptogea & 3.4 & $21 \mathrm{~b}$ & $0 \mathrm{~A}$ & $0 \mathrm{~A}$ & $21 \mathrm{bcB}$ \\
\hline Phytophthora megasperma & 0.5 & $3 \mathrm{a}$ & 0 & 0 & $3 \mathrm{a}$ \\
\hline Phytophthora pini & 0.8 & $5 \mathrm{a}$ & $0 \mathrm{~A}$ & $0 \mathrm{~A}$ & $5 \mathrm{abB}$ \\
\hline Phytophthora plurivora & 14.4 & $90 \mathrm{~d}$ & $0 \mathrm{~A}$ & $53 \mathrm{cC}$ & $37 \mathrm{~dB}$ \\
\hline Phytophthora syringae & 0.2 & $1 \mathrm{a}$ & 0 & $1 \mathrm{a}$ & $0 \mathrm{a}$ \\
\hline Phytophthora taxon raspberry & 0.3 & $2 \mathrm{a}$ & 0 & 0 & $2 \mathrm{a}$ \\
\hline Phytophthora $\times$ stagnum & 0.3 & $2 \mathrm{a}$ & 0 & 0 & $2 \mathrm{a}$ \\
\hline \multicolumn{6}{|l|}{ Pythium } \\
\hline Pythium aff. attrantheridium & 1.8 & $11 \mathrm{cde}$ & $11 \mathrm{bcB}$ & $0 \mathrm{~A}$ & $0 \mathrm{~A}$ \\
\hline Pythium aff. cederbergense & 0.2 & $1 \mathrm{a}$ & $1 \mathrm{a}$ & 0 & 0 \\
\hline Pythium aff. macrosporum & 12.7 & $79 \mathrm{~h}$ & $55 \mathrm{~dB}$ & $15 \mathrm{bA}$ & $9 \mathrm{bA}$ \\
\hline Pythium aff. rostratum & 0.3 & $2 \mathrm{ab}$ & $2 \mathrm{a}$ & 0 & 0 \\
\hline Pythium aff. undulatum & 0.3 & $2 \mathrm{ab}$ & 0 & $2 \mathrm{a}$ & 0 \\
\hline Pythium anandrum & 0.3 & $2 a b$ & 0 & 0 & $2 a b$ \\
\hline Pythium attrantheridium & 2.9 & $18 \mathrm{def}$ & $0 \mathrm{~A}$ & $0 \mathrm{~A}$ & $18 \mathrm{bB}$ \\
\hline Pythium cryptoirregulare & 31.7 & $198 \mathrm{i}$ & $82 \mathrm{eB}$ & $76 \mathrm{cB}$ & $40 \mathrm{cA}$ \\
\hline Pythium dissotocum & 5.8 & $36 \mathrm{~g}$ & $16 \mathrm{cA}$ & $12 \mathrm{bA}$ & $8 \mathrm{bA}$ \\
\hline Pythium intermedium & 0.8 & $5 a b c$ & $4 a b$ & $1 \mathrm{a}$ & 0 \\
\hline Pythium irregulare & 4.0 & $25 \mathrm{fg}$ & $19 \mathrm{c}$ & $2 \mathrm{a}$ & $4 a b$ \\
\hline Pythium litorale & 1.3 & $8 \mathrm{bcd}$ & $0 \mathrm{~A}$ & $0 \mathrm{~A}$ & $8 \mathrm{bB}$ \\
\hline Pythium mammilatum & 0.2 & $1 \mathrm{a}$ & 0 & 0 & $1 \mathrm{a}$ \\
\hline Pythium oopapillum & 0.2 & $1 \mathrm{a}$ & 0 & $1 \mathrm{a}$ & 0 \\
\hline Pythium oopapillum/dissotocum hybrid & 0.5 & $3 a b c$ & $3 \mathrm{ab}$ & 0 & 0 \\
\hline Pythium sp. ZSF0069 & 1.0 & $6 \mathrm{abc}$ & $5 \mathrm{ab}$ & $1 \mathrm{a}$ & 0 \\
\hline Pythium spiculum & 0.2 & $1 \mathrm{a}$ & 0 & $1 \mathrm{a}$ & 0 \\
\hline Pythium spinosum & 0.2 & $1 \mathrm{a}$ & $1 \mathrm{a}$ & 0 & 0 \\
\hline Pythium sylvaticum & 3.2 & 20 ef & $1 \mathrm{aA}$ & $0 \mathrm{~A}$ & $19 \mathrm{bB}$ \\
\hline Pythium undulatum & 0.2 & $1 \mathrm{a}$ & 0 & 0 & 1 \\
\hline Total species ${ }^{\mathrm{z}}$ & & 31 & 13 & 12 & 20 \\
\hline Phytophthora & 35.5 & $11 \mathrm{a}$ & $1 \mathrm{aA}$ & $3 \mathrm{aAB}$ & $10 \mathrm{aB}$ \\
\hline Pythium & 64.5 & $20 \mathrm{~b}$ & $12 \mathrm{bA}$ & $9 \mathrm{bA}$ & $10 \mathrm{aA}$ \\
\hline Total isolates & & 624 & 204 & 186 & 234 \\
\hline Phytophthora & 32.5 & $203 \mathrm{a}$ & $4 \mathrm{aA}$ & $75 \mathrm{aB}$ & $124 \mathrm{aC}$ \\
\hline Pythium & 67.5 & $421 \mathrm{~b}$ & $200 \mathrm{bA}$ & $111 \mathrm{bB}$ & $110 \mathrm{aB}$ \\
\hline Isolates of species $<3 \%$ of total & & 21 & 25 & 26 & 18 \\
\hline Phytophthora & 28.6 & $7 \mathrm{a}$ & $10 \mathrm{aA}$ & $9 \mathrm{aA}$ & $5 \mathrm{aA}$ \\
\hline Pythium & 71.4 & $14 \mathrm{a}$ & $15 \mathrm{aA}$ & $17 \mathrm{bA}$ & $13 \mathrm{bA}$ \\
\hline
\end{tabular}

${ }^{\mathrm{y}}$ Numbers of isolates for each species with lowercase letters within a column and genus and uppercase letters within a row are significantly different $(P<0.050)$.

${ }^{\mathrm{z}}$ Numbers of isolates for each genus with lowercase letters within a column and uppercase letters within a row are significantly different $(P<0.050)$. 
systems (53\%) than from propagation systems (2\%), with most species of Phytophthora occurring only in field systems ( 8 of 11 or $73 \%$ of Phytophthora species). Diversity indices showed similar trends (Fig. 4).

There were also shifts in the presence and abundance of individual species within each genus depending on the system type (Table 2). For the genus Pythium, Pythium cryptoirregulare, Pythium dissotocum, Pythium irregulare, and Pythium aff. macrosporum were the only four species found in all three system types. However, Pythium aff. macrosporum and Pythium irregulare were more common in propagation systems, whereas Pythium dissotocum was isolated with similar frequency across all three system types. Pythium cryptoirregulare was isolated in approximately equal numbers from both propagation and container systems but less often from field systems. However, as a percentage of total Pythium isolates, Pythium cryptoirregulare was isolated more frequently from container systems (76 of 111 or $68 \%$ ) than from either propagation ( 82 of 200 or $41 \%$ ) or field systems (40 of 110 or $36 \%)(P<0.001)$. Lastly, Pythium aff. attrantheridium was only found in propagation systems, whereas Pythium attrantheridium, Pythium litorale, and Pythium sylvaticum were mostly or only isolated from field systems.

For the genus Phytophthora, Phytophthora cinnamomi was the only species present in all three system types (Fig. 3; Table 2). It was rarely detected in propagation systems (only four plants from nursery D) and was isolated in greater numbers from field systems than container systems. However, as a percentage of total Phytophthora isolates, Phytophthora cinnamomi was isolated with equal frequency from both systems (container $=21$ of 75 or $28 \%$, field $=34$ of 124 or $27 \%$ ) $(P=0.929)$. Phytophthora plurivora was the most common Phytophthora species encountered in the survey $(P<0.050)$ but was never isolated from propagation systems. Based on both isolate counts and as a percentage of total Phytophthora isolates, Phytophthora plurivora was isolated much more frequently from container systems (71\%) than from field systems $(30 \%)(P<0.001)$, although much of this was attributable to the large number of Phytophthora plurivora isolates detected at nursery A (Table 3 ). The remaining nine Phytophthora species were only isolated from a single system (container or field), with the majority coming from field plants. Results were generally similar as described for shifts in Pythium and Phytophthora species abundances between the propagation system and container system at nursery $\mathrm{C}$ and between the container system and field system at nursery B (Table 3 ).

Species communities varied among nurseries but to a lesser degree than by system (Fig. 5; Table 3). Pythium cryptoirregulare was the only oomycete species found in all seven nurseries, whereas Pythium dissotocum, Pythium aff. macrosporum, Phytophthora cinnamomi, and Phytophthora plurivora were the next most frequently encountered species found at five or six nurseries each. Nursery A had the least oomycete richness of any of those surveyed, with only two Phytophthora species (Phytophthora cinnamomi and Phytophthora plurivora) and a single Pythium species (Pythium cryptoirregulare). Nursery F, on the other hand, had the greatest oomycete richness, with eight Phytophthora and nine Pythium species. Nursery F was also the only container or field nursery where Phytophthora cinnamomi was not isolated from any plants and had the least number of Phytophthora plurivora isolates of any nursery where this pathogen was present.

\section{Discussion}

This study represents the first survey focused on soilborne, rootinfecting Phytophthora species of rhododendron since 1974 (Hoitink and Schmitthenner 1974b). Although many other studies since then
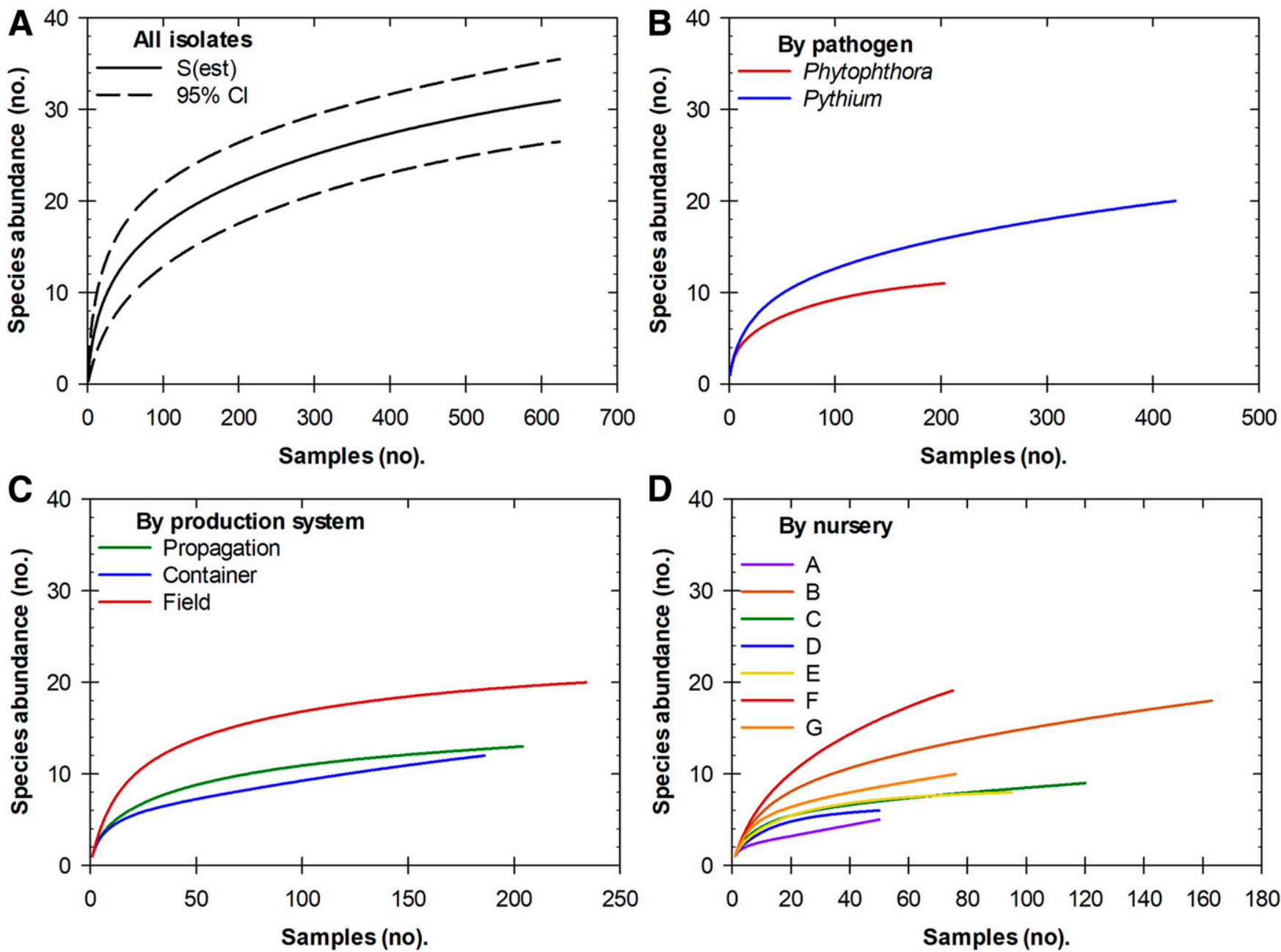

Fig. 1. Species richness curves $\mathbf{A}$, across all pathogens, nurseries, and production systems; $\mathbf{B}$, by pathogen genus; $\mathbf{C}$, by production system; and $\mathbf{D}$, by nursery. $\mathbf{S}$ (est) = estimated number of species and $\mathrm{Cl}=$ confidence interval. 
have indirectly reported on the diversity of soilborne Phytophthora species that infect rhododendron, results from those studies were often combined across hosts and sample types and this makes it difficult to make inferences about the community of root-infecting oomycetes that are specific to rhododendron production. Our results confirm that Phytophthora cinnamomi and Phytophthora plurivora are the most common Phytophthora species causing root rot of rhododendron (Weiland et al. 2018). This finding matches observations by Parke et al. (2014), who found that both species are common root pathogens of Kalmia, Pieris, Rhododendron, and Viburnum species in Oregon nurseries. Our finding also matches observations by Hoitink and Schmitthenner (1974b), who commonly isolated both
Phytophthora cinnamomi and Phytophthora citricola sensu lato. Their survey was conducted before Phytophthora citricola sensu lato was split into several other species, including Phytophthora plurivora, Phytophthora pini, and Phytophthora citricola sensu stricto (Hong et al. 2011; Jung and Burgess 2009), so it is impossible to know whether they might also have isolated Phytophthora plurivora specifically. In addition, Hoitink and Schmitthenner (1974b) isolated Phytophthora cinnamomi much more frequently during their survey than any other Phytophthora species and concluded that this pathogen was the most important species causing rhododendron root rot. This is in contrast to our observation that Phytophthora plurivora was more common than Phytophthora cinnamomi, which indicates


Nursery and production system

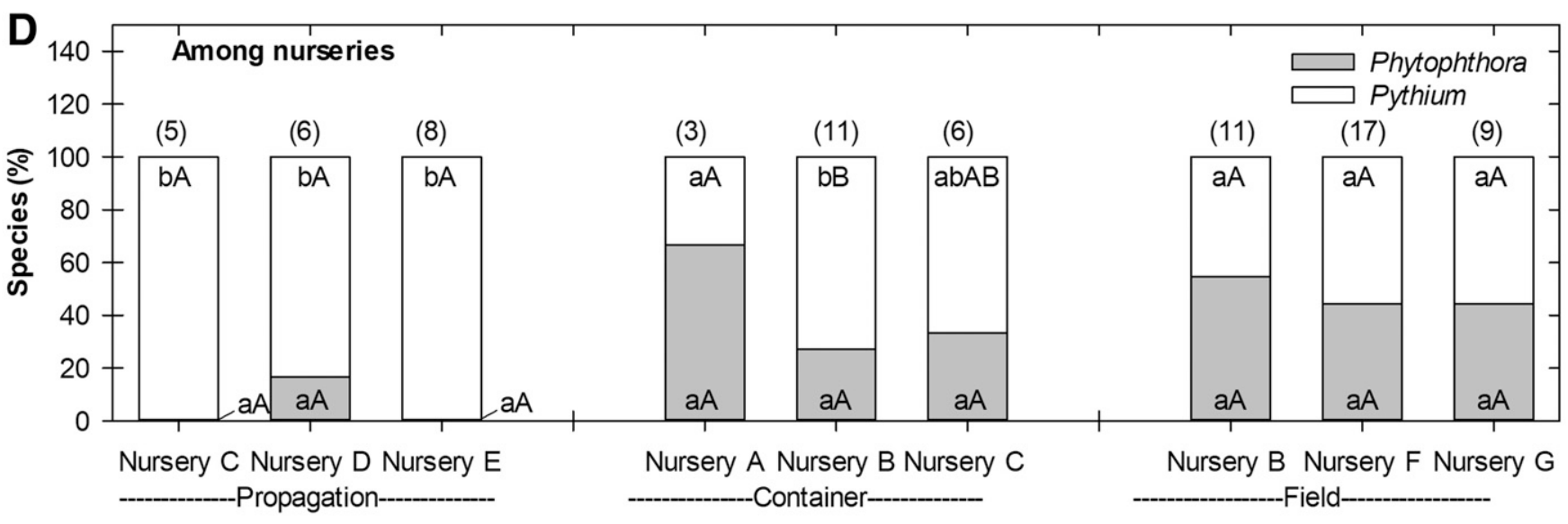

Nursery and production system

Fig. 2. Percentage of isolates and species of Phytophthora and Pythium from rhododendron plants in propagation, container, and field nursery production systems. Numbers in parentheses above columns are the total numbers for each group. A and B, Data for each genus across all nurseries in each production system. Significant $(P<0.050)$ differences between genera within a production system are denoted by lowercase letters and differences among production systems within a genus are denoted by uppercase letters. $\mathbf{C}$ and $\mathbf{D}$, Data for each genus from each nursery. Significant $(P<0.050)$ differences between genera within a nursery denoted by lowercase letters and differences among nurseries within a production system and genus are denoted by uppercase letters. 
that a shift in the diversity of rhododendron Phytophthora root pathogens has occurred since 1974. Our results were also different from surveys of Phytophthora species from rhododendron foliage and stems, which tended to more frequently find Phytophthora citrophthora, Phytophthora syringae, or Phytophthora cambivora, as well as Phytophthora plurivora (or Phytophthora citricola sensu lato) (Bienapfl and Balci 2014; Knaus et al. 2015; Parke et al. 2014; Prospero et al. 2013; Warfield et al. 2008). This highlights the ability of Phytophthora plurivora to infect both aboveground and belowground plant tissues (Jung and Burgess 2009; Weiland et al. 2010, 2018), a feature that may have contributed to this species becoming more common on rhododendron over time in comparison with Phytophthora cinnamomi, a primarily soilborne species. Analyses of the population structure of Phytophthora plurivora isolates from nurseries $\mathrm{A}, \mathrm{B}$, and $\mathrm{C}$ have further shown that most isolates are representative of a single clonal lineage (Carleson et al. 2019), providing additional support for the relatively recent spread of this species in the U.S. nursery industry (Beaulieu et al. 2017; Schoebel et al. 2014).

This study was the first to assess Pythium species diversity in rhododendron production and to show that Pythium cryptoirregulare and Pythium aff. macrosporum are the most common Pythium species isolated from rhododendron roots. Isolates of Pythium cryptoirregulare caused mild damage to two rhododendron cultivars in an earlier pathogenicity experiment (Weiland et al. 2018). Pythium aff. macrosporum, likely a new, undescribed Pythium species, was also detected in the soil of PNW forest nurseries and is capable of causing significant damping-off of Douglas-fir (Pseudotsuga menziesii) seedlings (Weiland 2011; Weiland et al. 2013). However, the ability of Pythium aff. macrosporum and other Pythium species identified from this survey to cause disease on rhododendron has not yet been tested. Root damage by these pathogens is expected to be minor given the lack of severe root rot in propagation houses where these pathogens were frequently isolated. Most Pythium species are considered mild pathogens that primarily cause root rot or damping-off in juvenile plant material, including cuttings (Moorman 2003; Weiland et al. 2018). Although Pythium dimorphum was identified as a cause of severe root rot of rhododendron in the past (Ho 1986), this pathogen has been rarely isolated since the initial report and was not found during our survey. Given the high frequency of Pythium detection from young rhododendrons in propagation houses, further research is needed to determine whether the presence of these pathogens may reduce the ability for cuttings to root.

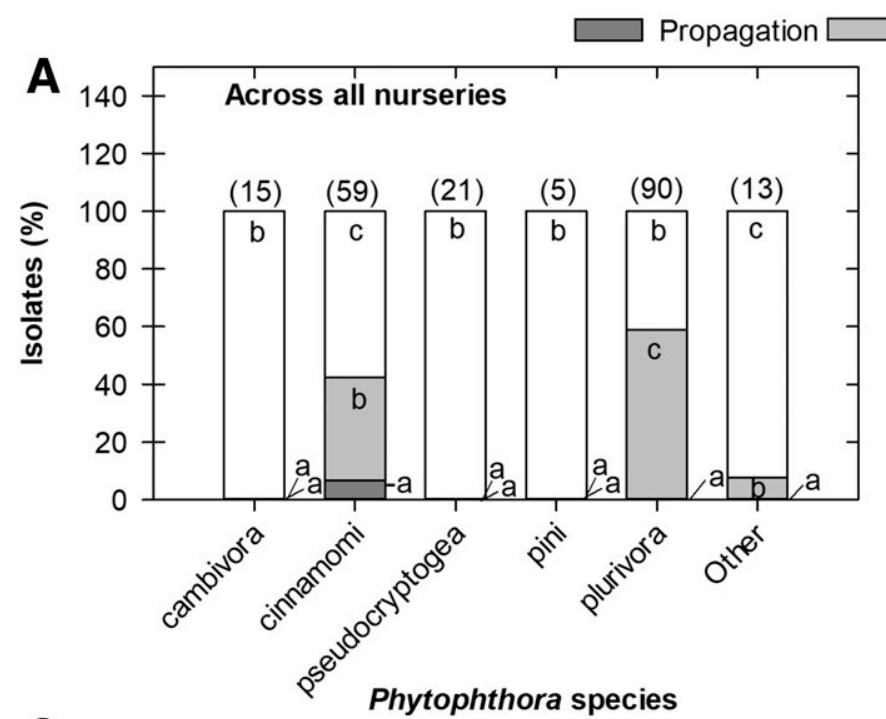

Container $\square$ Field

C
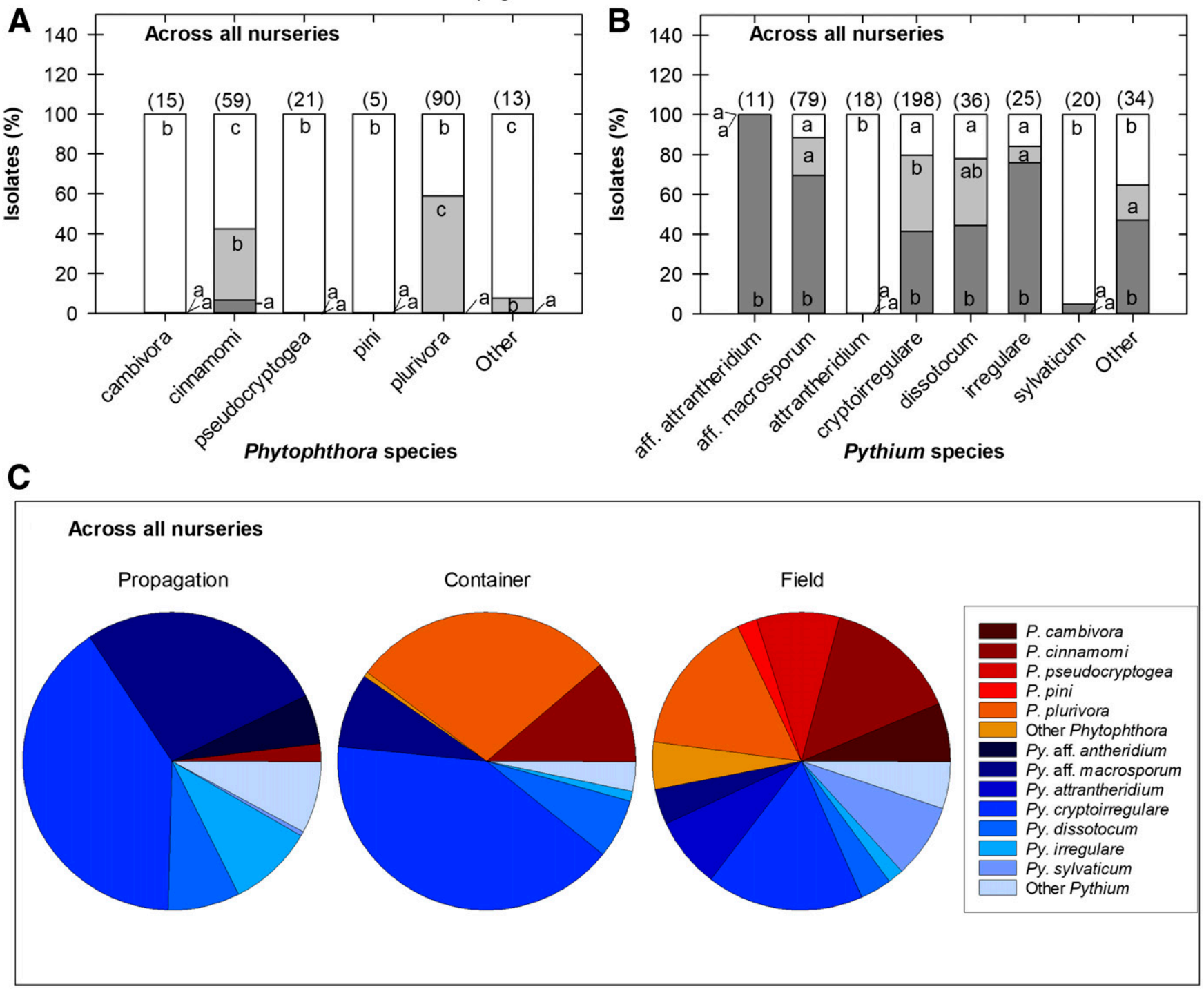

Fig. 3. Frequency of Phytophthora and Pythium species from rhododendron plants in propagation, container, and field nursery production systems. A and B, Data for each genus across all nurseries for each production system. Numbers in parentheses above columns are the total numbers for each species. Other species are those accounting for $<3 \%$ of the total number of isolates for each genus. Within a species, significant $(P<0.050)$ differences among systems are denoted by lowercase letters within columns. $C$, Species data for each production system across all nurseries. 


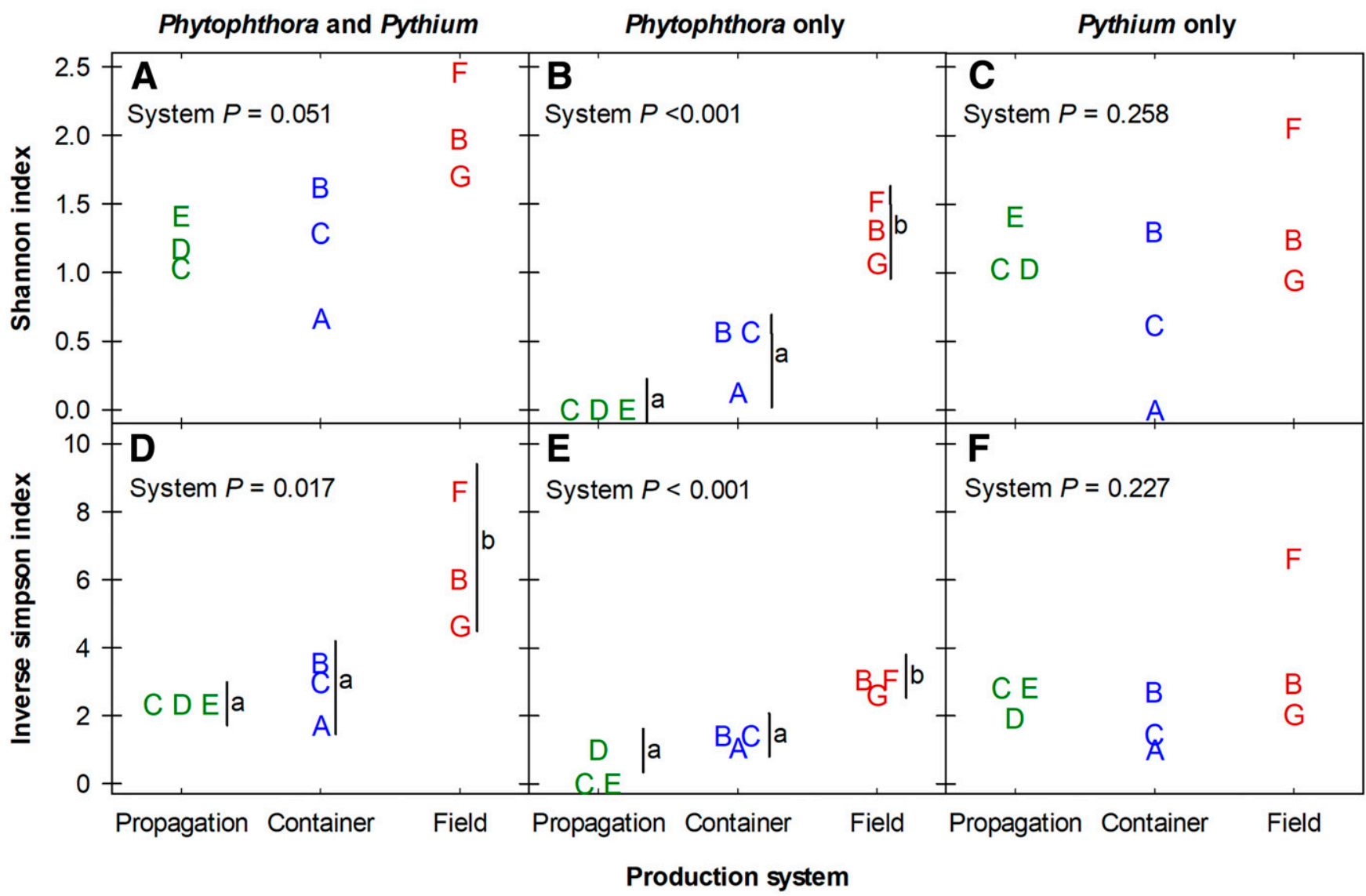

Fig. 4. Species diversity indices of Phytophthora and Pythium from rhododendron plants in propagation, container, and field production systems. A, B, and C, Shannon index for both genera Phytophthora and Pythium, genus Phytophthora only, and genus Pythium only, respectively. D, E, and F, Inverse Simpson index for both genera Phytophthora and Pythium, genus Phytophthora only, and genus Pythium only, respectively. Significant $(P<0.050)$ differences between production systems, determined by analysis of variance followed by the Tukey's honestly significant difference test, are denoted by lowercase letters within each panel.

Table 3. Five most common Phytophthora and Pythium species isolated from rhododendron plants in three propagation (C, D, and E), container (A, B, and C), and field (B, F, and G) nurseries

\begin{tabular}{|c|c|c|c|c|c|c|c|c|c|}
\hline \multirow[b]{3}{*}{ Genus and species } & \multicolumn{9}{|c|}{ Isolates $(n)$} \\
\hline & \multicolumn{3}{|c|}{ Propagation } & \multicolumn{3}{|c|}{ Container } & \multicolumn{3}{|c|}{ Field } \\
\hline & $\mathbf{C}$ & $\mathbf{D}$ & $\mathbf{E}$ & $\mathbf{A}$ & B & $\mathbf{C}$ & $\mathbf{B}$ & $\mathbf{F}$ & $\mathbf{G}$ \\
\hline \multicolumn{10}{|l|}{ Phytophthora $a^{\mathrm{y}}$} \\
\hline Phytophthora cambivora & - & - & - & - & - & - & $1 \mathrm{aA}$ & $14 \mathrm{bB}$ & $0 \mathrm{aA}$ \\
\hline Phytophthora cinnamomi & 0 & 4 & 0 & $1 \mathrm{aA}$ & $1 \mathrm{aA}$ & $19 \mathrm{cB}$ & $17 \mathrm{bB}$ & $0 \mathrm{aA}$ & $17 \mathrm{bB}$ \\
\hline Phytophthora pseudocryptogea & - & - & - & - & - & - & $5 \mathrm{aB}$ & $16 \mathrm{bC}$ & $0 \mathrm{aA}$ \\
\hline Phytophthora pini & - & - & - & - & - & - & $0 \mathrm{aA}$ & $0 \mathrm{aA}$ & $5 \mathrm{aA}$ \\
\hline Phytophthora plurivora & - & - & - & $36 \mathrm{bB}$ & $10 \mathrm{bA}$ & $7 \mathrm{bA}$ & $16 \mathrm{bB}$ & $2 \mathrm{aA}$ & $19 \mathrm{bB}$ \\
\hline \multicolumn{10}{|l|}{ Pythium } \\
\hline Pythium aff. macrosporum & $1 \mathrm{aA}$ & $2 \mathrm{aA}$ & $52 \mathrm{cB}$ & $0 \mathrm{aA}$ & $15 \mathrm{cB}$ & $0 \mathrm{aA}$ & $1 \mathrm{aA}$ & $8 \mathrm{bB}$ & $0 \mathrm{aA}$ \\
\hline Pythium attrantheridium & - & - & - & - & - & - & $17 \mathrm{bB}$ & $1 \mathrm{aA}$ & $0 \mathrm{aA}$ \\
\hline Pythium cryptoirregulare & $34 \mathrm{cB}$ & $32 \mathrm{bB}$ & $16 \mathrm{bA}$ & $13 \mathrm{aA}$ & $35 \mathrm{~dB}$ & $28 \mathrm{bB}$ & $16 \mathrm{bB}$ & $2 \mathrm{abA}$ & $22 \mathrm{cB}$ \\
\hline Pythium dissotocum & $5 \mathrm{aAB}$ & $0 \mathrm{~A}$ & $11 \mathrm{bB}$ & $0 \mathrm{aA}$ & $8 \mathrm{bcB}$ & $4 \mathrm{aAB}$ & $3 \mathrm{aA}$ & $4 \mathrm{abA}$ & $1 \mathrm{aA}$ \\
\hline Pythium irregulare & $19 \mathrm{bB}$ & $0 \mathrm{aA}$ & $0 \mathrm{aA}$ & $0 \mathrm{aA}$ & $1 \mathrm{aA}$ & $1 \mathrm{aA}$ & $0 \mathrm{aA}$ & $3 \mathrm{abA}$ & $1 \mathrm{aA}$ \\
\hline Total species ${ }^{\mathrm{z}}$ & 5 & 6 & 8 & 3 & 11 & 6 & 11 & 17 & 9 \\
\hline Phytophthora & $0 \mathrm{a}$ & $1 \mathrm{a}$ & $0 \mathrm{a}$ & $2 \mathrm{aA}$ & $3 \mathrm{aA}$ & $2 \mathrm{aA}$ & $6 \mathrm{aA}$ & $8 \mathrm{aA}$ & $4 \mathrm{aA}$ \\
\hline Pythium & $5 \mathrm{bA}$ & $5 \mathrm{aA}$ & $8 \mathrm{bA}$ & $1 \mathrm{aA}$ & $8 \mathrm{aA}$ & $4 \mathrm{aA}$ & $5 \mathrm{aA}$ & $9 \mathrm{aA}$ & $5 \mathrm{aA}$ \\
\hline Total isolates & 60 & 50 & 94 & 50 & 76 & 60 & 83 & 74 & 76 \\
\hline Phytophthora & $0 \mathrm{aA}$ & $4 \mathrm{aA}$ & $0 \mathrm{aA}$ & $37 \mathrm{bB}$ & $12 \mathrm{aA}$ & $26 \mathrm{aB}$ & $42 \mathrm{aA}$ & $40 \mathrm{aA}$ & $42 \mathrm{aA}$ \\
\hline Pythium & $60 \mathrm{bA}$ & $46 \mathrm{bA}$ & $94 \mathrm{bA}$ & $13 \mathrm{aA}$ & $64 \mathrm{bC}$ & $34 \mathrm{aB}$ & $41 \mathrm{aA}$ & $34 \mathrm{aA}$ & $34 \mathrm{aA}$ \\
\hline Isolates of species $<3 \%$ of total & 9 & 8 & 6 & 2 & 4 & 4 & 7 & 7 & 5 \\
\hline Phytophthora & $0 \mathrm{a}$ & $0 \mathrm{a}$ & $0 \mathrm{a}$ & $1 \mathrm{aA}$ & $3 \mathrm{aA}$ & $2 \mathrm{aA}$ & $4 \mathrm{aA}$ & $2 \mathrm{aA}$ & $3 \mathrm{aA}$ \\
\hline Pythium & $9 \mathrm{bA}$ & $8 \mathrm{bA}$ & $6 \mathrm{bA}$ & $1 \mathrm{aA}$ & $4 \mathrm{aA}$ & $2 \mathrm{aA}$ & $4 \mathrm{aA}$ & $7 \mathrm{aA}$ & $2 \mathrm{aA}$ \\
\hline
\end{tabular}

${ }^{\mathrm{y}}$ Numbers of isolates for each species with lowercase letters within a column and genus and uppercase letters within a row and production system are significantly different $(P<0.050)$.

${ }^{\mathrm{z}}$ Numbers of isolates for each genus with lowercase letters within a column and uppercase letters within a row and production system are significantly different $(P<$ $0.050)$. 
Since the first discovery of Phytophthora species as a cause of rhododendron root rot in 1930, research on disease development and control has focused almost exclusively on Phytophthora cinnamomi as the causal agent (Benson 1986, 1990; Benson and Parker 2005; Blaker and MacDonald 1981; Englander et al. 1980; Hoitink and Schmitthenner 1974a, b; Krebs 2013; Manning and Crossan 1966; McGuire and Jackson 1973; Ownley and Benson 1991; White 1930). However, our results indicate that Phytophthora plurivora is now at least as common as Phytophthora cinnamomi in both container and field systems and is also capable of causing severe root rot (Weiland et al. 2018). Other Phytophthora species are present and may likewise be important in causing disease, particularly at nurseries where they are more abundant. Nursery F, for example, had a very different community profile with more Phytophthora species than any other nursery (Table 3). This may have been attributable in part to the fact that this was the only surveyed container or field nursery that did not use fungicides to control root rot. Regardless, research on the ability of these other Phytophthora species to cause disease either alone or in combination with other species is needed because there are likely differences in biology, environmental responses, infection, and disease development that remain largely unexplored (Hoitink and Schmitthenner 1974b; Weiland et al. 2018). In addition, research is needed to assess whether these other Phytophthora species respond in a similar manner to disease control measures that were developed for Phytophthora cinnamomi. For example, isolates of Phytophthora citricola sensu lato from various hosts, including rhododendron, were generally less sensitive to metalaxyl than those of Phytophthora cinnamomi (Coffey et al. 1984). The active component of this fungicide, mefenoxam, is still in use for Phytophthora root rot control; if similar differences are observed among rhododendron isolates of Phytophthora pini and Phytophthora plurivora compared with those of Phytophthora cinnamomi, this could lead to a shift in soilborne Phytophthora communities toward more fungicide-resistant species and disease control failure. Whether other Phytophthora species respond in a similar manner to the host, fungicides, temperatures, or moisture regimes as Phytophthora cinnamomi is generally not known, and any differences may partially explain why practices developed for Phytophthora cinnamomi sometimes fail to adequately control root rot caused by other Phytophthora species in PNW nurseries (J. E. Weiland, personal observation).

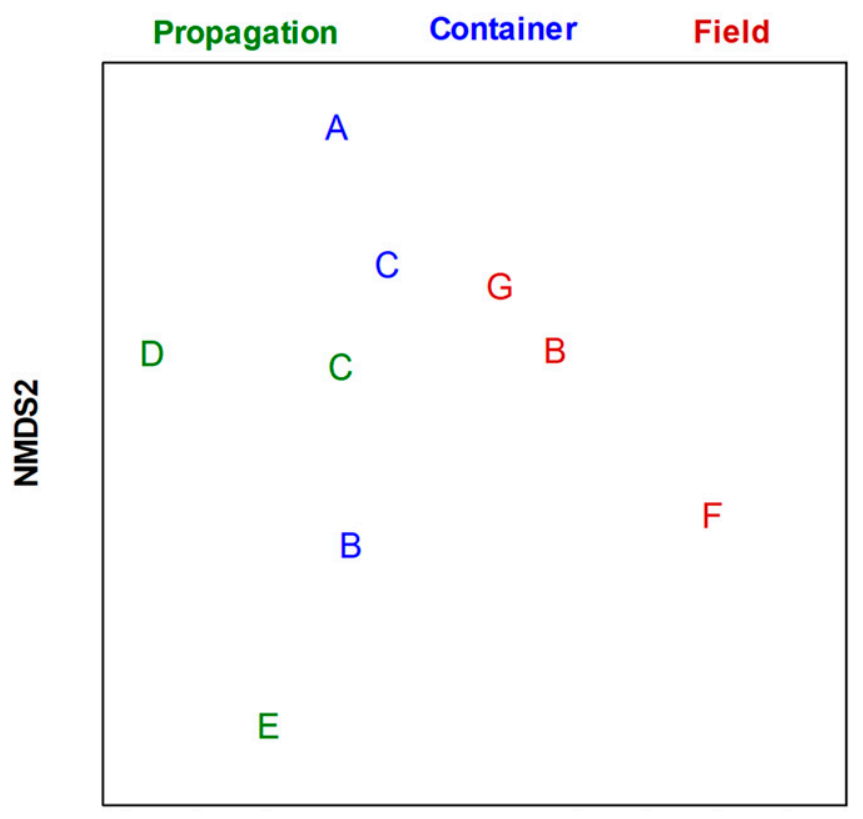

\section{NMDS1}

Fig. 5. Nonmetric multidimensional scaling (NMDS) of Bray-Curtis dissimilarities between nursery communities. Letters indicate the nursery and colors indicate the production system. Points closer together have more similar communities than points further apart.
Our disease survey results show that rhododendron root rot remains a serious problem for the rhododendron industry. For example, nursery F lost $90 \%$ of the crop from a 0.2 -ha field consisting of approximately 2,000 rhododendrons aged 2 and 3 years to root rot at a cost of almost $\$ 25,000$. This nursery had the highest incidence of root rot of any nursery surveyed (41\%) and was the only nursery that did not use fungicides to manage root rot. This might explain why nursery $\mathrm{F}$ also had the greatest number of Phytophthora and Pythium species of any nursery surveyed. In comparison, the nursery with the fewest number of detected oomycete pathogens, nursery A, uses two fungicides (mefenoxam and phosphorous acid) and a proprietary biocontrol blend to manage disease. Despite this, nursery A had the same incidence of root rot (12\%) as the other two container nurseries (B and $\mathrm{C}$ at 14 to $15 \%$ ) that use mefenoxam and phosphorous acid without biocontrol, and nursery A had more root rot than field nursery $\mathrm{G}(3 \%)$, which used both fungicides combined with frequent culling of unhealthy plants. These observations suggest that fungicides are at least somewhat effective for reducing root rot incidence and oomycete pathogen diversity, but there is still some residual oomycete pathogen activity capable of causing disease. It is therefore worth exploring how fungicides may change oomycete pathogen communities toward more fungicide-tolerant species or whether there has been selection for fungicide-resistant isolates in the nursery industry. Ultimately, combining fungicides with cultural and other disease control measures may provide the best control.

Symptoms of root rot were uncommon and Phytophthora species were rarely isolated from the rhododendron plants sampled from propagation systems in our survey. This matches observations by Parke et al. (2014), who seldom detected Phytophthora species from plants, media, or containers during the early stages of production. Rhododendron plants in the nurseries we surveyed were propagated only by stem cuttings and therefore posed a very low risk for moving soilborne Phytophthora species into propagation systems. Sanitation was also generally greater at this stage compared with container and field production stages. Cuttings were monitored frequently and any dying cuttings were usually promptly removed. In addition, most nurseries used new flats and new soilless media for each new batch of cuttings. The one exception occurred at nursery D, which was the only nursery where the genus Phytophthora (Phytophthora cinnamomi) was detected from the propagation stage. This nursery used raised wooden benches to root cuttings and the soilless rooting medium in the benches had been reused for a number of years. This likely allowed Phytophthora cinnamomi to survive, proliferate, and to cause root rot once it had been accidentally introduced into the system. Unfortunately, a Phytophthora contamination issue also developed later at nursery E (after the survey) where disease scouting and sanitation had become less stringent since the survey was originally conducted. These findings further illustrate the importance of sanitation for managing root rot, especially during early stages of production.

The sharp increase in the incidence of root rot and in the isolation of the genus Phytophthora from container and field systems suggests that the greatest risk for contamination comes in after the propagation stage. During the survey, we commonly observed several practices that likely introduced and spread or maintained Phytophthora inoculum in the production stream. Materials used to produce soilless media (sawdust, bark, perlite, pumice, or sand) were sometimes stored on open field soil next to plant production blocks where root rot was present. Ideally, these materials would be kept on concrete pads to reduce contamination by any inoculum residing in field soil. In some cases, pots were reused without proper cleaning, which could potentially transfer inoculum to the next generation of plants (Parke et al. 2014). Poor drainage, overirrigation, and leaking or malfunctioning irrigation equipment was also common, leading to frequent flooding in field soils or to puddling of water in container beds. These conditions promote the production and movement of zoospores, and they increase the likelihood of infection and spread of Phytophthora species through nursery beds. Similar situations have been observed in other nursery studies (Parke and Grünwald 2012). 
The presence of dead or dying plants was a consistent problem in most of the surveyed nurseries that could function as a continuous reservoir of Phytophthora inoculum for contaminating nearby healthy plants. With the exception of nursery $\mathrm{G}$, which has a rogueing program to remove unhealthy plants as soon as they are discovered, plants with symptoms of root rot were common in many of the container and field sites at the other nurseries. Although these symptomatic plants are not sold, nearby healthy plants might be contaminated with Phytophthora species as a result of their proximity to the infected plants (Fig. 6) and subsequently sold or possibly exported out of state. Dead plants may also have served as a direct source of inoculum at nursery A, which periodically composts dead plant material from the production stream and then uses the resulting compost as an amendment when potting new plants. If critical killing temperatures were not reached and composting was incomplete, Phytophthora inoculum could potentially survive and be spread to new plants. Multiple studies have shown that Phytophthora and Pythium species are frequently moved across state and national borders on infected nursery stock (Bienapfl and Balci 2014; Jung et al. 2016; Migliorini et al. 2015). Contaminated or infected plants with few or no symptoms of disease pose a significant risk for spreading soilborne pathogens throughout the nursery industry. Studies to evaluate low levels of inoculum (Weiland et al. 2018) and the potential for asymptomatic, but contaminated plants to spread soilborne pathogens and develop disease later are needed to better evaluate this risk.

In summary, our survey shows that root rot is still a significant problem in the PNW rhododendron industry. We now have a better understanding of the diversity of soilborne Phytophthora and Pythium species infecting rhododendron and have evidence for a shift in species abundance over time from Phytophthora cinnamomi toward Phytophthora plurivora. This knowledge has allowed us to compare the pathogenicity of the three most common species (Phytophthora cinnamomi, Phytophthora plurivora, and Pythium cryptoirregulare) using PNW isolates (Weiland et al. 2018) and enables future disease control research to focus on the root-infecting oomycete species that are the most prevalent in the industry and cause the
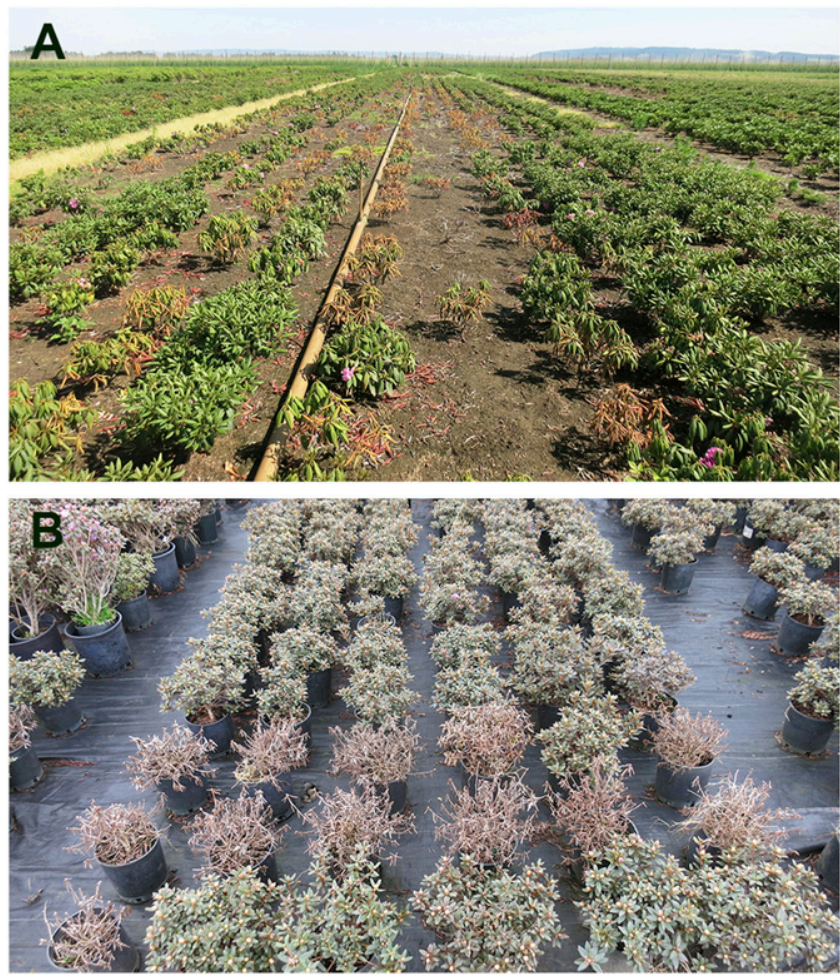

Fig. 6. Rhododendron plants with symptoms of root rot occurring next to asymptomatic plants in $\mathbf{A}$, a field site at nursery $\mathrm{F}$ and $\mathrm{B}$, a container site at nursery $\mathrm{B}$. most damage. Disease control methods that were developed for Phytophthora cinnamomi may not be as effective for other Phytophthora species and more research is needed to explore whether there are significant differences in biology among species that affect disease development and control. Our survey also showed that most root rot damage is occurring after the propagation stage, in the container and field systems. This damage coincides with an increased presence and diversity of Phytophthora species and suggests that most disease control efforts should be targeted toward these production stages.

\section{Acknowledgments}

We gratefully acknowledge Angie Mestas for technical assistance.

\section{Literature Cited}

Beaulieu, J., Ford, B., and Balci, Y. 2017. Genotypic diversity of Phytophthora cinnamomi and P. plurivora in Maryland's nurseries and Mid-Atlantic forests. Phytopathology 107:769-776.

Benson, D. M. 1986. Relationship of soil temperature and moisture to development of Phytophthora root rot of azalea. J. Environ. Hortic. 4:112-115.

Benson, D. M. 1990. Landscape survival of fungicide-treated azaleas inoculated with Phytophthora cinnamomi. Plant Dis. 74:635-637.

Benson, D. M., Jones, R. K., and Barker, K. R. 1982. Disease loss assessment for azalea, rhododendron, and Japanese holly in North Carolina nurseries. Plant Dis. 66:125-128

Benson, D. M., and Parker, K. C. 2005. Efficacy of cyazofamid, fenstar, and other fungicides for control of Phytophthora root rot of azalea, 2004. Fungic. Nematicide Tests 60:OT013.

Bienapfl, J. C., and Balci, Y. 2014. Movement of Phytophthora spp. in Maryland's nursery trade. Plant Dis. 98:134-144.

Blaker, N. S., and MacDonald, J. D. 1981. Predisposing effects of soil moisture extremes on the susceptibility of rhododendron to Phytophthora root and crown rot. Phytopathology 71:831-834.

Blomquist, C. L., Yakabe, L. E., Rooney-Latham, S., McRoberts, N., and Thomas, C. 2016. Detection of Phytophthora ramorum in nurseries and forest lands in California in 2004 to 2009. Plant Dis. 100:139-148.

Botha, W. J., and Crous, P. W. 1992. A wilt disease of rhododendron caused by Pythium prolatum and Cylindrocladium scoparium. Phytophylactica 24:75-78.

Carleson, N. C., Fieland, V. J., Scagel, C. F., Weiland, J. E., and Grünwald, N. J. 2019. Population structure of Phytophthora plurivora on Rhododendron in Oregon nurseries. Plant Dis. 103:1923-1930.

Coffey, M. D., Klure, L. J., and Bower, L. A. 1984. Variability in sensitivity to metalaxyl of isolates of Phytophthora cinnamomi and Phytophthora citricola. Phytopathology 74:417-422.

Colwell, R. K. 2013. EstimateS: Statistical estimation of species richness and shared species from samples. Version 9.1.0. User's Guide and Application, published at: http://viceroy.eeb.uconn.edu/EstimateS/EstimateSPages/ EstSUsersGuide/EstimateSUsersGuide.htm

Dart, N. L., and Chastagner, G. A. 2007. High recovery rate of Phytophthora from containerized nursery stock pots at a retail nursery highlights potential for spreading exotic oomycetes. Plant Health Prog. 8:48.

Englander, L., Merlino, J. A., and McGuire, J. J. 1980. Efficacy of two new systemic fungicides and ethazole for control of Phytophthora root rot of Rhododendron, and spread of Phytophthora cinnamomi in propagation benches. Phytopathology 70:1175-1179.

Hendrix, F. F., Jr., and Campbell, W. A. 1966. Root rot organisms isolated from ornamental plants in Georgia. Plant Dis. Rep. 50:393-395.

Ho, H. H. 1986. Pythium dimorphum from rhododendron. Mycopathologia 93: 141-145.

Hoitink, H. A. J., and Schmitthenner, A. F. 1974a. Resistance of Rhododendron species and hybrids to Phytophthora root rot. Plant Dis. Rep. 58:650-653.

Hoitink, H. A. J., and Schmitthenner, A. F. 1974b. Relative prevalence and virulence of Phytophthora species involved in rhododendron root rot. Phytopathology 64:1371-1374.

Hong, C., Gallegly, M. E., Richardson, P. A., and Kong, P. 2011. Phytophthora pini Leonian resurrected to distinct species status. Mycologia 103:351-360.

Jung, T., and Burgess, T. I. 2009. Re-evaluation of Phytophthora citricola isolates from multiple woody hosts in Europe and North America reveals a new species, Phytophthora plurivora sp. nov. Persoonia 22:95-110.

Jung, T., Orlikowski, L., Henricot, B., Abad-Campos, P., Aday, A. G., Aguín Casal, O., Bakonyi, J., Cacciola, S. O., Cech, T., Chavarriaga, D., Corcobado, T., Cravador, A., Decourcelle, T., Denton, G., Diamandis, S., Doğmuş-Lehtijärvi, H. T., Franceschini, A., Ginetti, B., Green, S., Glavendekić, M., Hantula, J., Hartmann, G., Herrero, M., Ivic, D., Jung, M. H., and Lilja, A. 2016. Widespread Phytophthora infestations in European nurseries put forest, semi-natural and horticultural ecosystems at high risk of Phytophthora diseases. For. Pathol. 46:134-163.

Kannwischer, M. E., and Mitchell, D. J. 1978. The influence of a fungicide on the epidemiology of black shank of tobacco. Phytopathology 68:1760-1765. 
Knaus, B. J., Fieland, V. J., Graham, K. A., and Grünwald, N. J. 2015. Diversity of foliar Phytophthora species on Rhododendron in Oregon nurseries. Plant Dis. 99:1326-1332.

Krebs, S. 2013. Resistance to Phytophthora root rot varies among rhododendrons subjected to repeated flooding in the field. Acta Hortic. 990:243-253.

Manning, W. J., and Crossan, D. F. 1966. Evidence for variation in degree of pathogenicity of isolates of Phytophthora cinnamomi to broadleaf and coniferous evergreens. Plant Dis. Rep. 50:647-649.

Mantel, N. 1974. Comment and suggestion on the Yates continuity correction. J. Am. Stat. Assoc. 69:378-380.

McGuire, J. J., and Jackson, N. 1973. Influence of environment on incidence of Phytophthora root rot in four varieties of rhododendrons in containers. Am. Rhod. Soc. 27:120-123.

Migliorini, D., Ghelardini, L., Tondini, E., Luchi, N., Santini, A., and Richardson, D. M. 2015. The potential of symptomless potted plants for carrying invasive soilborne plant pathogens. Divers. Distrib. 21:1218-1229.

Moorman, G. W. 2003. Damping-off of seeds and seedlings and cutting rot. Pages 46-47 in: Diseases of Woody Ornamentals and Trees in Nurseries. R. K. Jones and D. M. Benson, eds. American Phytopathological Society, St. Paul, MN.

Morris, E. K., Caruso, T., Buscot, F., Fischer, M., Hancock, C., Maier, T. S., Meiners, T., Müller, C., Obermaier, E., Prati, D., Socher, S. A., Sonnemann, I., Wäschke, N., Wubet, T., Wurst, S., and Rillig, M. C. 2014. Choosing and using diversity indices: Insights for ecological applications from the German Biodiversity Exploratories. Ecol. Evol. 4:3514-3524.

Oksanen, J., Blanchet, F. G., Friendly, M., Kindt, R., Legendre, P., McGlinn, D., Minchin, P. R., O'Hara, R. B., Simpson, G. L., Solymos, P., Stevens, M. H. H., Szoecs, E., and Wagner, H. 2019. vegan: Community Ecology Package. R package version 2.5-4. https://cran.r-project.org/web/packages/ vegan/index.html

Ownley, B. H., and Benson, D. M. 1991. Relationship of matric water potential and air-filled porosity of container media to development of Phytophthora root rot of rhododendron. Phytopathology 81:936-941.

Parke, J. L., and Grünwald, N. J. 2012. A systems approach for management of pests and pathogens of nursery crops. Plant Dis. 96:1236-1244.
Parke, J. L., Knaus, B. J., Fieland, V. J., Lewis, C., and Grünwald, N. J. 2014 Phytophthora community structure analyses in Oregon nurseries inform systems approaches to disease management. Phytopathology 104:1052-1062.

Prospero, S., Vercauteren, A., Heungens, K., Belbahri, L., and Rigling, D. 2013. Phytophthora diversity and the population structure of Phytophthora ramorum in Swiss ornamental nurseries. Plant Pathol. 62:1063-1071.

Schoebel, C. N., Stewart, J., Grünwald, N. J., Rigling, D., and Prospero, S. 2014 Population history and pathways of spread of the plant pathogen Phytophthora plurivora [published corrections appear in PLoS One 2014;9:e106209 and e105259]. PLoS One 9:e85368.

Schwingle, B. W., Smith, J. A., and Blanchette, R. A. 2007. Phytophthora species associated with diseased woody ornamentals in Minnesota nurseries. Plant Dis. 91:97-102.

USDA National Agricultural Statistics Service. 2015. 2014 Census of Horticultural Specialties. https://www.nass.usda.gov/Surveys/Guide_to_NASS_Surveys/ Census_of_Horticultural_Specialties/index.php

Warfield, C. Y., Hwang, J., and Benson, D. M. 2008. Phytophthora blight and dieback in North Carolina nurseries during a 2003 survey. Plant Dis. 92: 474-481.

Weiland, J. E. 2011. Influence of isolation method on recovery of Pythium species from forest nursery soils in Oregon and Washington. Plant Dis. 95:547-553.

Weiland, J. E., Beck, B. R., and Davis, A. 2013. Pathogenicity and virulence of Pythium species obtained from forest nursery soils on Douglas-fir seedlings. Plant Dis. 97:744-748.

Weiland, J. E., Nelson, A. H., and Hudler, G. W. 2010. Aggressiveness of Phytophthora cactorum, P. citricola $I$, and P. plurivora from European beech. Plant Dis. 94:1009-1014.

Weiland, J. E., Scagel, C. F., Grünwald, N. J., Davis, A., Beck, B. R., and Fieland V. J. 2018. Variation in disease severity caused by Phytophthora cinnamomi, $P$. plurivora, and Pythium cryptoirregulare on two rhododendron cultivars. Plant Dis. 102:2560-2570.

White, R. P. 1930. Two Phytophthora diseases of rhododendron. Phytopathology 20:131.

White, R. P. 1937. Rhododendron wilt and root rot. N. J. Agric. Exp. Stn. Bull. 615. 